\title{
"Who'll be a witness for my Lord?" Witnessing as an Ecclesiological and Missiological paradigm
}

\section{Andrew G. Suderman ${ }^{1}$}

\begin{abstract}
The Christian church's expansive zeal has often, throughout its history, walked handin-hand with the colonial pursuits of empires and nation-states. This cooperative approach between church and empire, which has been described as a Christendom or Constantinian paradigm, has not only implicated the church in the oppression and violent exploitation of people, but, because this paradigm has shaped the church's ecclesial and missiological imagination, such violent and oppressive tendencies are perpetuated. This paper will argue that, in order to break free from such an understanding, we need to reimagine how we understand our ecclesial being and missional purpose. In remembering what it means to be "witnesses" of Jesus Christ in the early church, an understanding which, because of the lifestyle it required, was intimately connected with the very real possibility of becoming a martyr, we are challenged by this alternative paradigm to reimagine our ecclesial being and missional purpose. This alternative imagination, based on a self-sacrificial paradigm of power, changes the very nature and "witness" of the church and its mission.
\end{abstract}

Key words: power, witness, Christendom, Constantinianism, John Howard Yoder, William Cavanaugh, martyrdom

\section{Introduction}

A well-known African American spiritual that arose during the time of slavery in the southern U.S. asks a very poignant question - "Who'll be a witness for my Lord?" Even in a subordinated social position in society, there remained an assumption that one could give witness to Jesus Christ; they could and would witness to Jesus Christ through their mouths and through their bodies. And this form of witnessing - through proclamation and bodily sacrifice - during the time of slavery in the U.S. demonstrates its similarity with the experience of the early church. The notion of "witness" or "witnessing" in the time of the early church progressed in becoming virtually synonymous with becoming a martyr. Although there was a distinction

\footnotetext{
Andrew Suderman is a Mennonite Church Canada worker and serves as the Director of the Anabaptist Network in South Africa (ANiSA). He is also a PhD Candidate in the School of Religion, Philosophy and Classics at the University of KwaZulu Natal. He can be contacted at andrewgsuderman@gmail.com.
} 


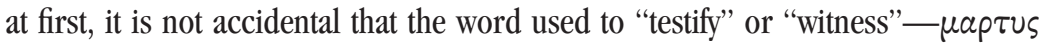
(martus) — eventually became the same word used for "martyr". Martyrdom, in other words, became a form of witnessing.

In the book of Acts, we see, as the book progresses, a growing connection between testifying and becoming a martyr because of what one testifies. Indeed, the book of Acts recounts the first act of a disciples' martyrdom - the killing of Stephen. And many more follow. Luke's promise that a disciple will be like his teacher (Luke 6:40) is fulfilled in Acts where the disciples, like their teacher, "both act and suffer for the truth of Christ in ways parallel to the action and suffering of Christ himself" (Willimon, 2010: 14).

But, these acts of martyrdom - acts that mimic the life of Jesus while also suffering the consequences of such a life - prove to be more than helpless victimization of those who witness to Jesus. Such acts are but the consequence of Jesus' followers embodying the alternative political agenda along with the different form of power that Jesus, in his life, demonstrated.

In this paper, I will seek to explore and demonstrate how Jesus' promise found in Acts 1:4-8, a promise of power to be witnesses of Jesus Christ, provides a basis for an alternative ecclesiological imagination, along with missiological implications that naturally follow, which challenges a Christendom based imagination and paradigm that has influenced the Christian church for much of its history. Jesus' promise provides a hint of a different type of power that forms the basis of this alternative paradigm; a form of power the disciples are meant to embody. It is a form of power that differs substantially from that of the empire, which is also, I will argue, the understanding of power that the church after Constantine has largely adopted. The promise of another form of power than that which the empire embraces - what I describe as an upside-down understanding of power - which the disciples receive through the Holy Spirit provides the ability for the church to respond to the all-too-apparent realities of violence, oppression, poverty, and inequality that exist in our society - traits that are common to the legacy of colonialism, in ways that pursue Kingdom of God traits peace, justice, and reconciliation - whilst embodying such traits.

\section{The Christendom paradigm}

The year 312 CE proved to be a significant year for the life of the church as a new relationship emerged between it and the empire. This marked the end of the persecution Christians suffered at the hands of the Roman Empire. It also marked the beginning of a shift whereby Christianity was not only tolerated but in fact became the compulsory form of religious expression within the empire (386 CE). This shift was the birth of what would later be called Christendom - the intimate relationship between the church and the empire (or the church and state later on) in how they 
would work together in making society "Christian." The interests of the church, in other words, became the interests of the empire, and the interests of the empire were intimately connected with that of the church.

The church welcomed this new relationship as a hope that had been fulfilled the time of suffering and death because of their faith had come to an end. One can hardly blame the church at this time for welcoming the change. Christians during this time saw Constantine and his efforts to legalize the Christian faith as an answer to prayer. Eusebius, for example, could hardly find phrases that would depict sufficiently this new Christian Emperor, calling Constantine "almost another Christ," "the only true philosopher," and a "vessel of the divine Logos." Constantine also saw himself in a similar light - depicting himself as a 13th disciple and as a bishop of the bishops (Yoder et al, 2009: 58) - a bishop ordained by God to oversee whatever is outside the church.

All of this formed a new relationship between the church and the empire. This newly found relationship began to shape the imaginations with regards to the roles and functions of the church and the empire. And this served as the formational base of Christendom. Harry Huebner highlights several traits that emerged as a result of the empire's conversion (Huebner, 2012: 61-62). ${ }^{2}$

First, a distinction emerged between the "visible" and "invisible" church. Whereas the church was a visible body before Constantine as a socially and publicly constituted visible counter-body, after Constantine the true church, true in the sense that it was a community of the faithful and committed, no longer assumed to be visible. The "true church" was now found internally, in the hearts of men and women for God alone to see (Huebner, 2012: 61). ${ }^{3}$

Second, there was a separation between the social and the spiritual. Whereas for early Christians the church was itself a political body in that it addressed issues of economics, governance, power, and enemies, the new relationship between the church and the empire introduced a division of labour - the church dealt with the spiritual and individual, whereas the empire dealt with the physical and political (Huebner, 2012: 61).

2 Although Huebner's recent book is entitled as an "introduction", one should not be fooled by its title of its academic rigor, reliability, and comprehensive historical argument. One only needs to pick up and begin reading Huebner's book to recognize that it is no ordinary "introductory" textbook. I use Huebner in this instance as he gives a good description of the shift that took place pre and post Constantine (i.e., through the "Constantinian Shift").

3 See also YODER, J. H. 1984. The Priestly Kingdom: Social Ethics as Gospel, Notre Dame, Indiana, University of Notre Dame Press. Yoder notes that, whereas before the Constantinian shift the church was in the minority, after the shift the whole Empire was now Christian. But the "true church" was still considered to be a minority, it was now simply hidden or invisible. Augustine, the major architect of the concept of the ecclesia invisibilis, believed that the true church was perhaps five percent of the visible one after Constantine (Yoder, 1984: 136). 
Third, this ecclesiological shift resulted in a different way of understanding the way God governed the world. Instead of working through the church's faithful (preConstantinian understanding), God now worked through the emperor. The role of the devoutly religious was to focus on the inner spiritual health of their leaders and provide advice and advocacy so that their leaders to make wise social decisions. The church, in accepting the invitation to operate within the power structure of the Empire, became irrelevant in how the world moves forward; it no longer had a direct role in the process or an alternative process - political practice - that challenged the ways of the Empire. Its "political" function was replaced with a purely "religious" purpose (Huebner, 2012: 61). Charles Villa-Vicencio notes:

The invitation by the Emperor Constantine in 312 CE to the church, hitherto persecuted and prevented from having any direct political influence, to operate from within the power structures of the state resulted in the church's capitulation to imperial demands. Constantine "achieved by kindness", it has been suggested, "what his predecessors had not been able to achieve by force" (Villa-Vicencio, 1992: 20). ${ }^{4}$

Fourth, a distinction between the "religious" and the "laity" emerged. In so far as one could speak about the visible church, it became associated with the church hierarchy (Huebner, 2012: 61). This dualism also introduced a distinct ethic between those who were "religious" from the "laity." John Howard Yoder, for example, notes how " $[t]$ he definitions of the faith could thus no longer take the assembly of believers as its base. As a result, therefore, the eyes of those looking for the church had to turn to the clergy, especially to the episcopacy, and henceforth 'the church' meant the hierarchy more than the people" (Yoder, 1984: 136). Indeed, Huebner notes how such a dualism possesses an inherent contradiction of the "Constantinian synthesis that affirms that everyone is Christian by law yet confesses at the same time that not everyone is Christian by conviction" (Huebner, 2012: 62). The empire even provided special exemptions to the "religious" as it was beneficial to the empire. Eusebius, for example, comments that "clergy were exempt 'from all public duties, that they may not by any error or sacrilegious negligence be drawn away from the service duty to the Deity, but may devote themselves without any hindrance to their law. For it seems that when they show greatest reverence to the Deity, the greatest benefits accrue to the state"” (Huebner, 2012: 61).

4 It should be noted that, although I have tried to consistently use terms such as "empire" and "state" according to their proper historical timeframe, thereby hoping to avoid any form anachronism, some of those whose work I quote, such as this quote from Villa-Vicencio, use terms such as "state" synonymously with "empire." The two, however, are used to refer to the ruling authorities of the day. 
And lastly, when Christianity encompasses everyone within the empire, an alternate guiding source than the Bible and the insights of the worshipping community are sought as the ethic of Jesus, it is assumed, is no longer "realistic" for the way society en total relates to one another. Ethical discourse, in other words, faces two particular tests in Christendom: 1) can you ask such behavior of everyone? 2) What would happen if everyone did it? (Yoder, 1984: 139) Thus, greater emphasis is placed on law and policy making for the empire as it is now the entity responsible for social and political matters.

The implications of this shift are substantial. This shift changes the ecclesiological character and witness of the church, its political involvement, as well as its missional focus. Whereas before Constantine the church was concerned for the way it followed and embodied the ways of Jesus, the church after Constantine became primary concerned for believing correctly (i.e., orthodoxy). Thus, a disconnect emerged between the beliefs of the church from the lived expression that sought to imitate Jesus' lived example. Indeed, due to the above traits of this shift, the church was no longer a particular - or peculiar - community as everyone in the empire was now, at least officially, part of the church.

Arne Rasmusson provides a good summary:

The Constantinian shift means that the church changes from being a minority to becoming the imperial religion of, with time, almost everyone. Not to be Christian thus required great conviction. This led to the creation of the doctrine of the invisible church as the true believers or the elect still were considered a small minority. The church thus no longer signified an identifiable people, but came to mean primarily the hierarchy and sacramental institution, with the consequence that faith and Christian life primarily were understood in inward terms (Rasmusson, 1995: 222). ${ }^{5}$

Allan Boesak likewise says:

Before the Constantinian period, the Christian Church was a band of people, ethnically and socially mixed, politically neither influential nor powerful. When under Constantine Christianity became a state religion, however, the Church changed.

5 For an excellent look at the Constantinian shift and the implications for how "conversion" (i.e., what it meant to become "Christian") was understood, see KREIDER, A. 1999. The change of conversion and the origin of Christendom, Harrisburg, Pa., Trinity Press International. See also John Howard Yoder's The Priestly Kingdom: Social Ethics as Gospel (Notre Dame, Indiana: University of Notre Dame Press, 1984), 135-147; The Original Revolution: Essays on Christian Pacifism (Waterloo, ON: Herald Press, 2003), 65-84; and "The Disavowal of Constantine: An Alternative Perspective on Interfaith Dialogue" in The Royal Priesthood: Essays Ecclesiological and Ecumenical, ed. by Michael G. Cartwright (WaterI00, ON: Herald Press, 1998), 242-261. See also Stanley Hauerwas, Against the Nations: War and Survival in a Liberal Society (Notre Dame, Indiana: University of Notre Dame Press, 1992), 74-78. 
From then on, Church and State would be allies. The confession of the Church became the confession of the State, and the politics of the State became the politics of the Church. The politics of the Kingdom of God would henceforth be subjected to the approval of Caesar (Boesak, 1977: 29). ${ }^{6}$

Through this shift, one of the most significant shifts to occur was the way in which "power" was understood and embodied. Through this shift, the church begins to assume and understand power the same way as the empire understood it. The result is that the church, in grappling with the question of power, begins to mimic the structure, approach, and sometimes the very goals of the empire itself. Charles Villa-Vicencio, for example, comments that

[o]ne of the consequences of the alliance between the historic Constantinian alliance between church and state has been the emergence of a hierarchy of control in the church similar to that which exists within the state. Indeed, in many situations the church is today more authoritarian, more hierarchical, more oppressive and less democratic, less participatory and less liberating than the state (Villa-Vicencio, 1992: 47).

Likewise, Yoder notes how, through the division of labour between the church and the empire, where the empire is now the entity concerned with matter outside of the church, thus with matters outside of the empire as everything inside of the empire is now "Christian," "mission" in the sense of calling one's hearers to faith in Jesus Christ also becomes redefined. "Beyond the limits of empire it had become identical with the expansion of Rome's sway" (Yoder, 1984: 137). Thus, not only did the change in understanding power affect the church's ecclesiology, but its missional purpose and identity as well.

Put another way, the church's imagination, through its intimate relationship with the empire, is re-shaped and begins to embrace the way the empire defines concepts such as "power." Power, the ability to affect something, including the way in which one relates to others (i.e., politics), came to be understood as a central characteristic of the empire as it was given the task to care for the social and the political within its territory. The church, therefore, released its understanding and definition of power and adopted the empire's understanding. The empire now simply relied on the church to justify and bless its use of power as its rightful handler through its practices and conquests.

6 Boesak, in fact, continues by saying that "the Fall of the Christian Church" through this Constantinian alliance is precisely when the Church became a white Church (29). 


\section{The Christendom imagination and the nation-state}

This Christendom paradigm shaped the church's imagination and its self-understanding. And so, even as the Renaissance, Reformation, and other more "political" events gave birth to the modern sense of the nation-state or nationhood, the church still largely assumed its Christendom or Constantinian role (Yoder, 1984: 141). In other words, although the symbiotic relationship the church enjoyed with the empire changed as the modern, liberal nation-state emerged, the church continued to assume, and continued to seek, its social relevance through the expressions of the nation-state. "The social arrangement remains, but on the national scale" (Yoder, 1984: 141). Yoder describes this as neo-Constantinianism.

William Cavanaugh provides a similar view surrounding the birth of the nationstate. Cavanaugh notes that the basic ecclesial assumption operating during the birth of the modern nation-state was that a country was viewed as an organic whole; the state would be responsible for the bodies, the church for the souls (Cavanaugh, 1998: 16). Indeed, " $[t]$ he church... had already handed the bodies of its members over to the state" (Cavanaugh, 1998: 16).

One of the principle myths that assisted the birthing of the modern nation-state was the often untested assumption that religion is violent in nature. It is often assumed, notes Cavanaugh, that the modern nation-state emerged because of and in response to the violent nature of religion (see Cavanaugh, 2009). Some suggested that the nation-state emerged as the one body that would be able to bring unity to those who held different doctrinal beliefs. The nation-state, in other words, emerged as the peace-maker, the entity that could truly bring about peace in the land as its citizens subordinate themselves for the common good. Religion, therefore, was relegated to the private life whereas loyalty to the sovereign state provided the necessary grounds to unite those who differed (Cavanaugh, 2009: 10). This, however, is not all that different from that which took place in the Constantinian shift and the assumed roles in Christendom where the political was separated from the spiritual and the social separated from the personal.

Cavanaugh challenges the myth that religion is intrinsically violent and argues that the commonly called "wars of religion" of the sixteenth and seventeenth centuries are in fact better understood as the birthpangs of the modern nation-state (Gingerich Hiebert) as it sought to become the one sovereign and objective body, thus ridding and/or subordinating other social bodies, such as the church, in its quest to be the peace-maker among differing and conflicting people prone to violence due to their doctrinal differences (Cavanaugh, 2009: 10). Cavanaugh concludes, however, that far from solving the problem of violence, there arose a change in what people were willing to kill for, namely the nation-state (Cavanaugh, 2009: 12). "Ostensibly, the holy was separated from politics for the sake of peace; in reality, 
the emerging state appropriated the holy to become itself a new kind of religion" (Cavanaugh, 2009: 11).

Cavanaugh acknowledges that the church was implicated in the wars of religion of the sixteenth and seventeenth century, and that these wars were really not simply about politics. "The point is that the transfer of power from the church to the state was not the solution to the violence of the sixteenth and seventeenth centuries, but was a cause of the wars. The church was deeply implicated in the violence, for it became increasingly identified with and absorbed into the statebuilding project" (Cavanaugh, 2009: 11-12). The church, therefore, dismantled itself as a social body and assumed its role of taking care of the moral well-being of the citizens while leaving the political, that is the social well-being of society, to the state. In effect, the church was relegated to the private realm where it assumed a chaplaincy role, while the state assumed its role as the one objective unified entity whose concern was the public welfare within its territory. Put simply, the logic of Christendom continued even upon the birth of the modern, liberal, nation-state.

And so, even in the birth of the liberal, secular, nation-state, the church has continued to assume the logic of Christendom and the way in which power is understood and embodied. The church, with its Constantinian imagination, has continued to understand power as that which rules over others in determining how society ought to be ordered and structured. And the role to wield such power is that of the empire or state. Within the church this has, historically, taken the form of mimicking the power structures of the empire - a top-down, hierarchically based understanding of power and authority - in order to effectively influence the empire or those "in power", i.e., those who rule, in how they order and rule over society. Put simply, the church has embraced the assumption that power is the ability to influence and order society through the empire or state. The church's role, if involved in any way, is to try to guide the way in which "the powers" use its power.

\section{The Power granted through the Holy Spirit}

Historically, the church, by and large, with a few notable exceptions, ${ }^{7}$ accepted the way in which the empire or the state understood power. This notion of power, however, is confronted with several incongruences when compared to the biblical narrative and its depiction of power, specifically Godly power, which the church is called to embrace and be led by. For example, a small and seemingly insignificant nation becomes the people of God; a child defeats a notorious warrior with pebbles

Some of the notable exceptions can be found, I think, in Anabaptism and its history as well as certain Liberation Theology movements whereby the power that is harnessed in challenging oppressive regimes is that of the people - a "power from below." In this way, there are many similarities between Liberation Theology and Anabaptism. 
and a sling shot; a savior is born in a barn to a carpenter; death, ironically, overcomes death and provides the possibility for life. All of these examples demonstrate the radically alternative way in which God works. They also, I think, demonstrate what we often miss - the paradoxical nature of God's power. God's work demonstrates an alternative reality as to what is possible and challenges us to align our lives according to such a reality. The difficulty, it seems, is not only aligning our lives and the way we participate in God's mission, but also to believe and trust in this seemingly illogical character of power embodied throughout the story of God's active presence in the world.

The promise Jesus makes to his disciples in the beginning of Acts helps us, I think, grapple with and better understand this alternative form and understanding of power.

Acts 1:4-8:

And being assembled together with them, He commanded them not to depart from Jerusalem, but to wait for the Promise of the Father, "which," He said, "you have heard from Me;

For John truly baptized with water, but you shall be baptized with the Holy Spirit not many days from now."

Therefore, when they had come together, they asked Him, saying, "Lord, will You at this time restore the kingdom to Israel?"

And He said to them, "It is not for you to know times or seasons which the Father has put in His own authority.

"But you shall receive power when the Holy Spirit has come upon you; and you shall be witnesses to Me in Jerusalem, and in all Judea and Samaria, and to the end of the earth."

The book of Acts begins with Jesus reminding his disciples of the promise he has made about the arrival of the Holy Spirit. This is the fulfillment of Jesus' promise that, once he departs, another helper would come to walk with, accompany, and strengthen the disciples in their journey of being like their teacher. This promise, the fire that the author already foretells in Luke 3:16, ${ }^{8}$ is fulfilled in Acts chapter 2 with the arrival of the Holy Spirit - i.e., the Pentecost event. We are led, in other words, to assume that with the fiery arrival of the Holy Spirit the promise which Jesus makes in Acts 1:4-8 is fulfilled: "you shall receive power when the Holy Spirit has come upon you..."

8 "John answered, saying to them all, "I indeed baptize you with water; but One mightier than I is coming, whose sandal strap I am not worthy to loose. He will baptize you with the Holy Spirit and with fire" (Luke 3:16). 
The rest of Acts goes on to demonstrate the way in which the Holy Spirit works in and through this newly formed community - the church; a community which was itself formed by the Holy Spirit. The Pentecost event marks a moment in which the power of God is bestowed upon Jesus' disciples. It also marks the moment in which the disciples received the power to follow the example of their teacher. The promise made in Luke 6:40, whereby "a disciple is not above his teacher, but everyone who is perfectly trained will be like his teacher" (Luke 6:40), is fulfilled through the lives of Jesus' disciples who, like Jesus, act and suffer because of the ways of Christ.

The key to understanding the ability of the disciples to behave like the example Jesus provided lies in understanding the purpose of the power they received from the Holy Spirit. In Acts 1:8 we find Jesus promising that the disciples "shall receive power when the Holy Spirit has come upon you; and you shall be witnesses to Me in Jerusalem, and in all Judea and Samaria, and to the end of the earth." The power that the disciples were to receive, in other words, would allow them to be witnesses to Jesus.

In order to better understand the significance of Jesus' promise as well as the apostle's actions after Pentecost, we must understand the meaning and significance of power (dunamis) and authority (exousia), especially as it used in both Luke and Acts; the two volumes written by the same author. These two words, dunamis and exousia are commonly used in reference to power. But the two are not synonymous. Indeed, there are some significant and interesting differences in how these two terms are used.

Dunamis is used 15 times in Luke and 10 times in the book of Acts. The author uses dunamis to refer to the ability to act. More than this, it refers to an activity that transforms things. In every instance, except for one (Luke 10:19), this term is used to describe either the characteristic and ability of God (e.g., "power of the most High"; "power of the Holy Spirit"; "power of the Lord"; "power of God"; etc.) or the extension of what is possible because of this Godly power (e.g., power to heal, power to caste out demons, power to do mighty works, power to do signs and miracles, etc.). Almost entirely, dunamis is used to describe the ability of God or those committed to acting in the ways of God to act in a way that transforms something.

Exousia is often used to describe power in relation to authority. The author of Luke-Acts uses this term to talk more about possessing the authority to act, rather than the ability to act itself. This term is used 16 times in Luke and 7 times in the book of Acts. Whereas dunamis is used in a positive sense except for one instance (Luke 10:19), exousia is more complex. Exousia is used positively when it refers to authority belonging to God or Jesus Christ. ${ }^{9}$ Yet 17 of the 23 times the author uses

9 e.g., Luke 4:32 \& 4:36 Jesus has authority over spirits; 5:24 Jesus has authority/power to forgive sins; 
exousia in a more negative way. It is more often used in an almost derogatory way in referring to those who are in positions that rule over others and in possession of "worldly", as opposed to Godly, authority..$^{10}$ Indeed, there are several instances where the author's use of exousia as authority to rule over others is the opposite of Godly power. ${ }^{11}$

In exploring the ways in which these two terms are distinguished in Luke-Acts, we can see how the form of power that is connected to exousia, that is possessing authority over others, is not, it seems, the way of Jesus or the desire of God. ${ }^{12}$ God

9:1 Jesus gives authority to the disciples to cast out demons and to heal; Acts 1:7 God has authority; 8:19 Simon requests for authority so that people could receive the Holy Spirit.

${ }_{10}$ E.g., Luke 4:6 refers to the authority that the devil possesses and provides; 7:8 refers to the authority the Centurion possesses over others; $12: 11$ refers to those who rule society - leaders in the synagogues, the magistrates, and the authorities; 19:17 refers to the authority a servant receives over cities; $20: 2$ the chief priests and scribes ask Jesus "by what authority are you doing these things?"; $20: 8$ Jesus does not respond to the question regarding authority; $20: 20$ notes that authority is possessed by the governor (particularly interesting considering the rest of the dialogue in the chapter that leads to this statement); 22:53 refers to the power of darkness; 23:7 refers to what is in Herod's jurisdiction; Acts 5:4 refers to the power/control that Ananias had over his own land and possessions; 9:14, 26:10, and $26: 12$ authority is in reference to the chief priests; and 26:18 refers to the power of Satan.

${ }^{11}$ Three examples will suffice in demonstrating this point. 1) In the temptations of Jesus, the devil speaks about the authority (exousia) he possesses and with which he tempts Jesus: "All this authority I will give You, and their glory; for this has been delivered to me, and I give it to whomever I wish" (Luke 4:6). Here exousia is a possession and a tool of the devil. 2) A second example can be found when Jesus' authority is questioned (Luke 20:1-8). Jesus is asked "by what authority are You doing these things [miracles, healing, driving out unclean spirits, etc.]?" Rather than getting into a battle about who has authority (exousia), Jesus, in a similar move to that of the temptations where Jesus failed to participate in the quest for the same type of authority that the devil possesses, side steps the question and refuses to participate in the system of ruling over, or having authority over, others. Interestingly, however, the author throws another reference in the same chapter that highlights that authority-this type of authority that Jesus sidesteps-is something which the governor possesses. Exousia, in other words, is again distinguished as a feature of worldly kingdoms or rulership, not a feature in the ways of God's kingdom (which again brings into perspective the second temptation of Jesus regarding the nature of the kingdoms of this world - Luke 4:5-8). 3) Lastly, in the final chapter in the book of Acts (Acts 26), there is an interesting interplay in the way exousia is used. Exousia is used 3 times in this chapter. The first two times it is used to describe the authority of the chief priests, a reference made to Paul's old life when he was persecuting the church. The last time, 26:18, it is used to describe the power of Satan. Although there are more examples that can be given, these three serve to demonstrate the point that exousia, when not referring to God's authority, is often used with a more negative connotation.

12 Note that I am not making a generalized conclusion about the nature of exousia in the whole New Testament. To do this we would need to look beyond Luke and Acts. I am here drawing this conclusion on the way this term is used in Luke and Acts. For a broader perspective in how such terms are used throughout the New Testament, see WINK, W. 1984. Naming the Powers: The Language of Power in the New Testament, Philadelphia, Pennsylvania, Fortress Press. What is noteworthy in Walter Wink's book, however, is that 85 percent of the time exousia is used in the New Testament it refers to a "structural dimension of existence" (ibid.), which are often depicted as fallen. See also YODER, J. H. 1994. The 
is the rightful possessor of authority (Acts 1:7), but authority over others is not the way in which power is to be embodied among Jesus' followers.

Instead, right after the author notes that God is the rightful possessor of authority (exousia), he specifies that the apostles shall receive power (dunamis) when the Holy Spirit descends upon them. The power (dunamis) or ability to act referred to in this verse is the ability to be witnesses to Jesus. The word that is translated as

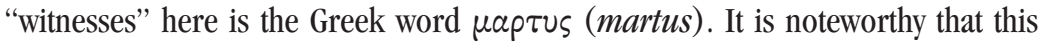
same word would later be used to describe those who would die because of their

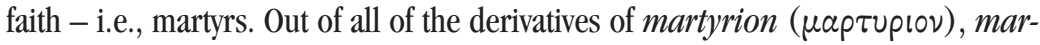
tus is the form most often used in the book of Acts (13 times). Although martus at first meant "to give witness to" or "to testify" and was not necessarily connected to death, it is significant that in a very short period of time - between $10-30$ years (depending on whether you ascribe to the idea that the book of Acts was written in the early 60's or in the 80's) - martus did become associated with death and martyrdom. ${ }^{13}$ Already in the book of Acts, for example, we are told about Stephen who becomes the first martyr. Others soon meet the same fate - Peter, Paul, and countless others in the early church. Christian faith and being a "witness" to Jesus Christ, in other words, became closely associated with martyrdom in the early years of the church. The bodies of the early Christians were, in a very literal way, given as a living sacrifice and testimony to God. Martyrdom became but one species of a larger narrative genre that comprehends the death of believers at the hands of hostile authorities within a wide range of other faithful practices that becomes a bodily witness to God's drama of salvation in the world (Fowl, 2011: 44).

Indeed, "witness" understood in this light, that is following Jesus Christ's example of self-sacrificial love for the other is closely related to the notion of kenosis found in the New Testament. Kenosis describes the understanding of divine selfemptying. It is based on the understanding that Jesus Christ, the second person of the Triune God, limited himself in becoming a person in order to live a human life. One could argue, as Hans von Balthasar did, that the idea of kenotic self-surrender is an all-pervasive characteristic of divine love itself, including within the perichoretic and reciprocal interrelations in the Trinity itself (Coakley, 2001: 199). Thus, Donald Dawe, in his The Form of a Servant: A Historical Analysis of the Kenotic

politics of Jesus : vicit Agnus noster, Grand Rapids, Michigan, Eerdmans.

${ }^{13}$ We can already see the connection between martus and death in several instances in the book of Revelation (e.g., Rev. 1:5, 2:13, 6:9, 12:11, 17:6). Scholars suggest that the book of Revelation was written in the 90's CE. There is ongoing debate as to when the book of Acts was written. Some argue that it was written in the 80 's, whereas others argue that it was written in the early 60 's. Either way, we can see how the meaning of martus began to shift from simply "testifying" to an understanding that intimately connected testifying with death and martyrdom. 
Motif, concludes that "[t]he divine kenosis is the key to the whole drama of human salvation" (Dawe, 1963: 17). Furthermore, the context of such a motif (e.g., Phil. 2:6-8 and 2 Cor. 8:9) emerged as a practical and ethical appeal. "The moral appeal of God's free self-giving is the motivation for the life of self-giving love for the Christian. God's free self-giving, his kenosis, describes the pattern of life for the Christian" (Dawe, 1963:17).

Thus, the power Jesus promises through the arrival of the Holy Spirit points to a vastly different understanding of power than that which emerged in the Christian church after Constantine. Whereas power in the post-Constantinian church has largely embraced the way empire defined power, a top-down, hierarchically based form of power and authority that seeks to affect the way society is ruled, which has meant forms of change brought about through force, domination, conquest, and control, the power that Jesus promises is one that allows those who receive it to act in a way that mimics the ways of Jesus and the desire of God. It is a promise of receiving dunamis that invites followers of Jesus to challenge injustice and violence, to heal, and to participate in mighty works in a way that is based on love, invitation, servanthood, and care for the other. The form of power that Jesus promises is one that allows those who receive it from the Holy Spirit to live in ways that imitate the life and kenotic example of Jesus, even if, like their teacher, it also leads to one's own death. ${ }^{14}$ The power of the Holy Spirit promised in Acts 1:8, in other words, is the power to live a life of self-denying love - an agape, kenotic love, an example of which was exemplified in the life and death of Jesus Christ.

\section{Implications of being a witness}

If we embrace and seek to embody this alternative form of power that Jesus promises when the Holy Spirit descends upon the disciples, it will change the way we live, the way in which we understand God's mission, and cause us to re-imagine the way in which we embody our ecclesial and missiological practices.

There are many implications that we could (and perhaps should) focus on. In this paper we will only look at three.

1) This first implication that arises from a paradigm of witness, which we already touched on earlier, is an enacted practice based on a different understanding of power - a power based on vulnerability and incarnation, which, at first glance, seems foolish. Our ability to "witness" to Jesus Christ means that we will not base or mimic forms of power that dominate, oppress, conquer, or force - forms of

${ }^{14}$ The World Council of Church's Commission on World Mission and Evangelism (CWME) describes this as receiving the inspiration from the Holy Spirit "to a self-emptying and cross-bearing life-style" as we bear witness "to the love of God in word and deed." See KEUM, R. D. J. 2013. Together Towards Life: Mission and Evangelism in Changing Landscapes. 
power that are violent in their very nature - even if it may lead to "Christianizing" those who are conquered. These characteristics are unfortunately all-too-common in ecclesiologies and missiologies that operate from a Christendom paradigm as this paradigm has embraced a post-Constantinian understanding of power and have often structured themselves accordingly. ${ }^{15}$

Interestingly, the World Council of Church's Commission on World Mission and Evangelism (CWME), in its "New Affirmation on Mission and Evangelism" recognizes the need to shift our missional understanding as it suggests a shift from "mission to the margins" to "mission from the margins" (Keum, 2013: 14-17). It notes how mission has often been an activity that has gone from the centre to the periphery, from the privileged to the marginalized of society (Keum, 2013: 5). However, "[m] ission expressed in this way has too often been complicit with oppressive and lifedenying systems. It has generally aligned with the privileges of the centre and largely failed to challenge economic, social, cultural, and political systems which have marginalized some peoples. Mission from the centre is motivated by an attitude of paternalism and a superiority complex" (Keum, 2013: 16).

Thus, rather than a Constantinian or Christendom based paradigm, a paradigm of witness operates from a confessional foundation - a foundation that cannot be forced.

Such a confessional foundation was so clear in the life of the early church that a theology of two baptisms emerged: the first by water, and the second by blood. The early church recognized that the act of confessing Jesus Christ as Lord - a politically loaded confession - could very well lead to their death. And yet, it was precisely this act of confession, even in the face of death, that demonstrated a different allegiance and a different understanding of power. Joerg Rieger, in looking at Philippians 2, notes that the humiliation and exaltation of Jesus provides a different sort of power which Jesus embodies: "a power that is in diametrical opposition to the power of the emperor" (Rieger, 2007: 43). And it was this diametrically alternative form of power that led to Jesus' own death as well as the death of many confessors in the early church.

And yet, it is in this way that martyrdom was (and is) missiological. Tripp York, in referring to Maximilian's example, notes that

[t]hough the empire killed [Maximilian] for his refusal to worship their gods, his act, as any act of martyrdom, was not against the empire - as if Christian witness

$15 \mathrm{~J}$. Kameron Carter, for example, introduces what he describes as the color of Constantinianism in how, with the advent of modernity, Christianity became a vehicle for white, European conquest because of this form of oppressive understanding of power and how it became severed from "the other" (i.e., Christianity's Jewish roots) who was foreign to European Christendom. "Remade into cultural and political property and converted into an ideological instrument to aid and abet colonial conquest, Christianity became a vehicle for the religious articulation of whiteness, though increasingly masked to the point of near invisibility" (Carter, 2008: 23). 
is merely reactionary or defined by what it is against. Rather, his martyrdom and early Christian martyrdom in general was for the empire. Any act of witness is always a testimony to the good news that is the resurrected Christ, which gives those watching the ability to see the world as it really is: redeemed (York, 2011: 23-24).

One's confessional stance causes him or her to be a witness of an alternative body politic, which puts into practice different ways of being that seeks to live rightly with one another, recognizing that this alternative way of being may lead to the same consequence as the one who inaugurated it. ${ }^{16}$

2) The second implication, which logically follows from the first, is that ecclesial and missiological practices that have as their foundation this alternative form of power the power to be witnesses - means that such practices are guided by the ability and the willingness to die for the other. The life Jesus lived thus provides the ultimate example. Throughout Jesus' life and teachings we can see his ongoing concern for people to live justly and in peace with one another. Put another way, through Jesus we see God's ongoing desire for his creation to live rightly with one another - that is live in just relationships. This tireless concern became embodied in a life and lifestyle whereby the cross became a politically motivated, legally-to-be-expected result of a moral clash with the principalities and powers. Jesus' example demonstrated - witnessed - the embodiment of a different form of power - one based on a self-sacrificial love rather than enacting violence and a willingness to kill.

Again, Tripp York says it well:

Martyrdom, the ultimate act of imitatio Christi, is a far more complex act of the Christian than a simple dying for one's principles (though that is no small feat).... $[\mathrm{T}]$ he early church understood martyrdom in general, and the body of the martyr in particular, as the arena for the cosmic battle between God and the power of evil, which begins with the public confession and culminates in the Christian's "second baptism." This is a baptism that is not just for the believer, but for the sake of the world. It is a liturgical rite at odds with the formative liturgy of the empire. It is an oath not to Caesar but to what is above Caesar for Caesar (York, 2011: 37).

Thus, a paradigm based on being witnesses will be concerned not only to participate in God's great shalom project, that is seeking peace and justice so that we may live rightly with one another and with God, but also in the way this project is pursued - imitating the ways of Jesus, even unto death. Both - embodying right

${ }^{16}$ Note, for example, paragraph 89 and 92 in KEUM, R. D. J. 2013. Together Towards Life: Mission and Evangelism in Changing Landscapes. 
relationships or dying towards that pursuit - provide a witness to Jesus and the kingdom he envisioned and inaugurated.

3) The final implication that derives from a paradigm based on being witnesses that we will look at (although there are many more) is the confidence in which we can now live because of the resurrection. Because of the resurrection we no longer need to live in fear in living lives that are based on the example and teaching of Jesus and the allegiance that we pledge to him. The Spirit received at Pentecost, and the power promised upon the Spirit's reception (Acts 1:8) "gives Christians courage to live out their convictions, even in the face of persecution and martyrdom" (Keum, 2013: 14).

Fear of death brings about more death. Yet Jesus demonstrates that death is defeated, ironically, through the willingness to die for the other. Through Jesus' death we have learnt that death no longer has the final word. Thus, even though witnessing to Jesus will cause us to live a life or embody a lifestyle that may result in our own deaths, we can live in confidence knowing that death has been defeated. Put simply, we need not fear death.

\section{Conclusion}

To embrace a paradigm based on being witnesses to Jesus Christ is to embrace and live according to an alternative understanding of power. The power which the Holy Spirit bestows is that which allows followers of Jesus to live in ways that demonstrate the same kind of self-sacrificial love that Jesus demonstrated through his life and death. Unlike the power that empires and states embody, which the church that continues to operate according to a Christendom paradigm has embraced, the power that the Holy Spirit provides is the ability to live and potentially die for the other. In this way we witness to Jesus Christ and the same kind of love that he exemplified.

If we understand "witness" and the power to be such in this way, and if we seek to live a life that is faithful to such an understanding, it cannot but affect our understanding of the church and its mission in the world. Questions pertaining to the way in which we understand the nature of the church, the way in which we structure it, and the mission or missional practices of such a community will be affected dramatically when we seek to embody a form of power that makes us vulnerable to the point of death out of love for the other. Such an interpretation, in other words, provides an alternative ecclesiological and missiological imagination.

\section{Bibliography}

Boesak, A. 1977. Farewell to innocence: A Social-Ethical Study of Black Theology and Black Power, Johannesburg, South Africa, Ravan Press. 
Cavanaugh, W. T. 1998. Torture and Eucharist: Theology, Politics, and the Body of Christ, Oxford, UK; Massachusetts, USA, Blackwell Publishers Ltd.

Cavanaugh, W. T. 2009. The Myth of Religious Violence: Secular Ideology and the Roots of Modern Conflict, New York, N.Y., Oxford University Press, Inc.

Coakley, S. 2001. "Kenosis: Theological Meanings and Gender Connotations". In Polkinghorne, J. 2001. The Work of Love: Creation as Kenosis, Grand Rapids, Michigan, Wm. B. Eerdmans.

Dawe, D. 1963. The Form of a Servant: A Historical Analysis of the Kenotic Motif, Philadelphia, Pennsylvania, Westminster Press.

Fowl, S. 2011. "The Primacy of the Witness of the Body to Martyrdom in Paul". In Budde, M. and Scott, K. Witness of the Body: The Past, Present, and Future of Christian Martyrdom, Grand Rapids, Michigan, William B. Eerdmans.

Gingerich Hiebert, K. 2012. Book Review of The Myth of Religious Violence: Secular Ideologies and the Roots of Modern Conflict by William T. Cavanaugh, The Heythrop Journal, vol. 53, no. 3 .

Huebner, H. 2012. An Introduction to Christian Ethics: History, Movements, People, Waco, Texas, Baylor University Press.

Keum, R. D. J. 2013. Together Towards Life: Mission and Evangelism in Changing Landscapes.

Kreider, A. 1999. The change of conversion and the origin of Christendom, Harrisburg, Pa., Trinity Press International.

Rasmusson, A. 1995. The Church as Polis: From Political Theology to Theological Politics as Exemplified by Jürgen Moltmann and Stanley Hauerwas, Notre Dame, Indiana, University of Notre Dame Press.

Rieger, J. 2007. Christ \& Empire: From Paul to Postcolonial Times, Minneapolis, Minnesota, Fortress Press.

Villa-Vicencio, C. 1992. A Theology of Reconstruction: Nation-building and human rights, Cape Town, South Africa, David Philip Publishers Ltd.

Willimon, W. 2010. Acts, Louisville, Kentucky, Westminster John Knox Press.

Wink, W. 1984. Naming the Powers: The Language of Power in the New Testament, Philadelphia, Pennsylvania, Fortress Press.

Yoder, J. H., Koontz, T., Alexis-Baker, A. 2009. Christian attitudes to war, peace, and revolution, Grand Rapids, Michigan, BrazosPress.

Yoder, J. H. 1984. The Priestly Kingdom: Social Ethics as Gospel, Notre Dame, Indiana, University of Notre Dame Press.

Yoder, J. H. 1994. The politics of Jesus: vicit Agnus noster, Grand Rapids, Michigan, Eerdmans.

York, T. 2011. "Early Church Martyrdom: Witnessing For or Against the Empire?" In Budde, M. and Scott, K. Witness of the Body: The Past, Present, and Future of Christian Martyrdom, Grand Rapids, Michigan, William B. Eerdmans. 